Martin Durrell and Richard J. Whitt

\title{
The development of the würde + infinitive construction in Early Modern German (1650-1800)
}

DOI 10.1515/bgsl-2016-0028

\begin{abstract}
This paper presents a corpus-based analysis of the evolution of the würde + infinitive construction in German during the Early Modern period (16501800), using newly available data from the GerManC-corpus. We demonstrate how this construction occupies a unique position orthogonal to both the tense and mood systems of German through an analysis of the syntax and semantics of würde + infinitive clauses, beginning with Modern Standard German and then subsequently with a historical focus on the late seventeenth and eighteenth centuries. Through both quantitative and qualitative analyses, we examine the contexts in which the construction occurs and see how, as it came to be used more frequently over the period in question, it encroached more and more into contexts which had been the preserve of the synthetic preterite subjunctive, even being used in some where the latter is still the norm in modern German. Thus, by the end of the eighteenth century it had become difficult to identify a clear difference in meaning and use between these forms, and the reasons why the würde + infinitive construction may be preferred over the synthetic preterite subjunctive are by no means clear. We conclude our discussion with an overview of how the würde + infinitive construction was received in the prescriptive tradition during this key period in the standardization of German, seeing its stigmatization in some contexts in part as an attempt by prescriptive grammarians to establish an explicit and clearly justified role for it in the language. ${ }^{1}$
\end{abstract}

1 The authors must acknowledge their gratitude to Mikhail Kotin (Zielona Góra) and Szilvia Szatzker (Budapest) who kindly made unpublished material available to them, as well as to Christopher Young (Cambridge) for clarifying queries about some MHG texts, and to two anonymous reviewers for the PBB for their helpful suggestions. The GerManC-corpus project was funded by grants from the British research councils ESRC and AHRC (RES-000-22-1609 and RES-062-23-1118).

Prof. Dr. Martin Durrell: The University of Manchester, School of Arts, Languages and Cultures, Oxford Rd., Manchester, M 13 9PL, United Kingdom, E-Mail: martin.durrell@manchester.ac.uk

Dr. Richard J. Whitt: The University of Nottingham, School of English, University Park, Nottingham, NG7 2NR, United Kingdom, E-Mail: richard.whitt@nottingham.ac.uk 


\section{Introduction}

The status and development of the German verbal periphrasis with the preterite subjunctive of werden and an infinitive, sometimes referred to as the sconditional or the `würde-form « has attracted considerable interest in recent years. Its place in the verbal system of modern German is still a matter of debate, and its use has long been the subject of intense prescriptive activity by normative grammarians and arbitrators of ıgood ‘ usage, as outlined in Durrell (2007). The origin and development of the construction since the Middle Ages is also not perfectly understood in all details, although considerable progress has been made to this end in the recent studies by Kotin (2003), Smirnova (2006, 2007) and Szatzker (2002, 2003, 2012). However, research into the development and use of the construction in the seventeenth and eighteenth centuries has been hampered by the lack of a sufficient body of reliable and representative data. This is now available in the form of the GerManC-corpus of German from 1650 to 1800 , and our primary aim in this paper will be to complement the studies just mentioned by presenting a systematic account of the development of the construction during the period covered by this corpus. In doing this we wish in particular to investigate whether any further light may be shed on the reasons why certain uses of the construction came to be stigmatized in the slong nineteenth century, since the prescriptions concerning its use appear to have emerged precisely at the end of the period under investigation.

We begin (section II) with basic details about the corpus itself, its structure and the principles by which it was compiled. A brief account is then given in section III of the meanings and use of the würde periphrasis in modern German, in particular in order to come to an understanding of the reasons why analyzing its role in the verbal system of the language has proved so difficult. This will provide the framework for an investigation of the diachronic development of the construction, the earliest stages of which are outlined in section IV on the basis of recent research. From this we will be able to identify the principal contexts in which the construction became established by the beginning of the early modern period, and these will provide a framework for analyzing the occurrences of the construction in the GerManC-corpus, and in section $\mathrm{V}$ we examine in detail the use of the periphrasis with würde between 1650 and 1800, as attested in the corpus texts. The findings are summarized in section VI, with conclusions about how the role, meaning and usage of the construction developed during the late seventeenth and eighteenth centuries, and a discussion of how these conclusions might further our understanding of the reasons for the stigmatization of the construction in the nineteenth century. 


\section{The GerManC-corpus}

The GerManC-corpus, which was compiled at the University of Manchester (UK) between 2006 and 2012, is a representative electronic corpus of German in the Early Modern period (1650-1800). ${ }^{2}$ It thus covers the period between the (conventionalized) end of the Early New High German (ENHG) period in 1650 and the relatively final stages of the process of codification at the end of the $18^{\text {th }}$ century, cf. Scheible et al. (2011a, 2011b). For the period up to 1650 the Bonn Corpus of Early New High German (`Bonner Frühneuhochdeutschkorpus`) is available, cf. Lenders and Wegera (1982), and this was used by Smirnova (2006) for her study, but no comparable resource has previously been available for the following period, despite its importance for the relatively final stages in the process of standardization of the written language. There are well-known problems in aiming for representativeness in the compilation of electronic corpora, cf. Durrell (2015), McEnery and Hardie (2012, pp. 8-11) and Wegera (2013), but in order to provide a coherent basis for systematic investigation of the linguistic development of German, it is clearly essential for a corpus to have an explicit and adequately justified structure in order to provide as broad and balanced a picture as possible of this historical stage of the language. In particular it seemed crucial to include a wider span of registers than the purely literary texts which have hitherto been the main focus of diachronic studies of German. Following this principle, texts for the corpus were selected according to the notion of representativeness developed by Biber for the ARCHER corpus of English, cf. Biber et al. (1993), which is acknowledged to provide a satisfactory model for representative diachronic corpora and incorporates texts from all the registers which are attested for the periods in question.

For German a total of eight registers was found to provide sufficient material for the period in question: newspapers, narrative prose (not only fiction), drama, legal texts, sermons, personal letters, scientific texts and texts on humanities-based topics. ${ }^{3}$ In order to permit historical developments in the language to be traced, the time-span of 150 years was divided into three sub-periods of fifty years, following

2 Further information regarding the GerManC-project may be found on the project website http://www.alc. manchester.ac.uk/subjects/german/research/projects/germanc/ (last accessed: 18.08.2016). The corpus is available in the Oxford Text Archive (http://ota.ox.ac.uk/desc/2544, last accessed: 18.08.2016), the LAUDATIO archive in Berlin (http://www.laudatio-repository.org/ repository/, last accessed: 18.08.2016) and the COSMAS II archive at the Institut für Deutsche Sprache in Mannheim https://cosmas2.ids-mannheim.de/cosmas2-web// (last accessed: 18.08.2016).

3 The registers are commonly abbreviated in the remainder of this paper, especially in the tables, in the form in which they appear in the corpus file name, i. e. DRAM (drama), HUMA (humanities 
the model successfully employed in the Bonn Corpus of Early New High German. Regional variation had to be fully taken into account given its continued importance during this period, but as this had diminished markedly by the mid-seventeenth century a less fine-meshed model than that employed in the Bonn Corpus of Early New High German was appropriate, with five broad regional divisions, i.e. North German (NG), West Central German (WCG), East Central German (ECG), West Upper German (including Switzerland) (WUG) and East Upper German (including Austria) (EUG). Texts from North Germany had to be included because High German had largely replaced the native Low German in print by 1650.

These three parameters proved adequate to cover the level of variation still present in the language, and for the completed corpus three 2000-word text samples were selected for each subdivision in terms of register, sub-period and region, and the corpus thus contains nearly 800,000 words. This is a relatively small corpus, but it reflected what could practically be achieved given the time and resources available, cf. Scheible et al. (2011a, 2011b).

\section{III. würde + infinitive in modern standard German}

The place of this form in the tense/mood paradigms of modern German has long been regarded as unclear and problematic, as may be seen from the detailed account of recent analyses of the construction and its presentation in descriptive grammars by Smirnova (2006, pp. 11-40). Eisenberg (1989, p. 137), for example, wrote in the second edition of his >Grundriss der deutschen Grammatikı: »Wir müssen zugestehen, daß die Stellung der würde-Formen im Paradigma unverstanden ist«. In a more recent edition (Eisenberg 2006, p. 124), he is less negative, but still sees the form as »nicht ins traditionelle Verbparadigma integriert«, and Zifonun et al. (1997, p. 1735) see the form similarly as "systematisch neben dem Paradigma«.

Until relatively recently, most accounts of the German verb since Behaghel (1924, pp. 243-246), e. g. Bausch (1979, p. 316), Drosdowski/Henne (1980, p. 625), Helbig/Buscha (1986, pp. 191 f.), Jäger (1971, pp. 251 ff.) and Weinrich (2003, p. 246) treated the construction as basically modal and thus essentially a periphrastic alternative to the synthetic preterite subjunctive which it has largely supplanted in usage, especially where the forms of the latter are identical to those of the indicative, as is the case with weak verbs. The fourth edition of the >DudenGrammatikı (Duden 1984, p. 158), is typical of this view in stating clearly: »Die

texts), LEGA (legal texts), LETT (letters), NARR (narrative prose), NEWS (newspaper texts), SCIE (scientific texts), SERM (sermons). 
Formen des würde-Gefüges unterscheiden sich in ihrer Funktion nicht von den einfachen und periphrastischen Formen des Konjunktivs II «. However, some earlier studies pointed out that the construction can also express relationships which are primarily temporal rather than modal, in particular a sfuture-in-the-past`, i. e. to refer to an event subsequent to a reference time in the past, but (normally) prior to the moment of speaking, cf. Comrie (1985, p. 128), and that in such contexts the würde-construction might not always be semantically equivalent to the preterite subjunctive and may not be replaced by it. This was already recognized by Erdmann (1886, p. 133) but his insight appears not to have been taken up at the time, and the usage was identified again by Herdin $(1903,1905)$, who thought it was a relatively recent innovation in the narrative device known as serlebte Reder (free indirect discouse), cf. Steube (1985). His account was widely derided by contemporary prescriptivists, cf. Durrell (2007), but Paul (1920, p. 148) also saw a function of the construction as temporal, saying that it was »ein Mittel [...], ein zukünftiges Geschehen vom Standpunkte der Vergangenheit aus $\mathrm{zu}$ bezeichnen«, and the >Deutsches Wörterbuch` (DWb 29, 255), gives examples of the use of the construction using almost identical phrasing to Paul.

Nevertheless, the fact that the würde-construction could have uses which are primarily temporal and not semantically equivalent to those of the preterite subjunctive was subsequently overlooked or ignored for many years, whether in specialized studies or general grammars of German, until the extensive and very clear account of them in Jørgensen (1966, pp. 27-29, 35-41), who pointed out the frequent use of the würde-form in contexts requiring the expression of futurity from a past perspective. On the basis of this he proposed that the form in this usage should be considered as part of the indicative paradigm, as a >Future Preterite (i. e. future-in-the-past) with a homonymous subjunctive form expressing epistemic modality, for which he used the traditional appellation >Conditionalı. This proposal was taken up and brought to widespread attention in the influential study by Thieroff (1992, pp. 140-159), who also showed clearly the limitations of the traditional view, detailing its frequent use not only in free indirect discourse, but also in other contexts requiring the expression of the time relationship of past futurity and followed Jørgensen (1966) in proposing that the form in this sense was part of the indicative paradigm, as a FuturPräteritum >future-in-the-past «. Like Jørgensen, he proposed that the modal meanings of the form should be assigned to a homonymous counterpart in the subjunctive system which he calls >Konjunktiv FuturPräteritum`, cf. Thieroff (1992, pp. 265-267). This analysis has not been widely accepted, in particular because of the extensive use of the würde-construction as a periphrastic alternative to the preterite subjunctive, where any expression of time is secondary, cf. Fabricius-Hansen (2000, p. 92), Kotin (2003, pp. 222-225) and Zifonun et al. (1997, p. 1738), but it is now 
generally acknowledged that the observation by Jørgensen (1966) and Thieroff (1992) is correct insofar as the form is more frequently used to express a purely temporal relationship than had previously been generally acknowledged and, crucially, that it cannot be substituted by the preterite subjunctive in such contexts. This use of the würde-construction is by no means restricted to such devices of written narration as free indirect discourse, but it is used in all registers to express the temporal relationship of past futurity, e. g.:

1) Ich habe gewusst, dass sie ihren Mann bald verlassen würde.

2) Es war doch von vornherein sicher, dass sie kommen würde.

Indeed, this is the only usual way in German to express this temporal relationship, since, as already recognized by Erdmann (1886, p. 133), the synthetic preterite subjunctive is ungrammatical in such contexts, cf.:

1a) ${ }^{\star}$ Ich habe gewusst, dass sie ihren Mann bald verließe.

2a) ${ }^{\star}$ Es war doch von vornherein sicher, dass sie käme.

As Schröder (1959, p. 72) already said, cf. Thieroff (1992, p. 157): "Sobald die Umschreibung mit würde + Infinitiv stark futurischen Charakter hat, kann der Konjunktiv Präteriti überhaupt nicht für sie eintreten «. The würde-construction is thus not simply a periphrastic alternative to the preterite subjunctive but has temporal uses exclusive to itself.

On the other hand, not all temporal uses are quite as distinct from those where the form is semantically equivalent to the preterite subjunctive as is asserted by Smirnova (2006, 2007), who distinguishes two semantic varieties of the construction (Lesarten, in her terms), cf. especially Smirnova (2007, p. 20). The first is »die analytische Alternative zum synthetischen Konjunktiv II«, for which she gives the example:

3) "Das war, als hätte man einen Teddybär dabei«, erzählt die Managerin, »oder als würde man mit einem Menschen sprechen" (Spiegel 1994, p. 36)

Here würde sprechen could be replaced by spräche without any distinction in meaning. In the second variety the würde-construction functions as a marker of evidentiality, expressing an inference on the part of the speaker, cf. Smirnova (2006, pp. 61-107, 131-155). This variety is particularly evident in complement clauses depending on a non-factive verb such as annehmen, denken, glauben, hoffen, überlegen, vermuten or zweifeln, or a similar expression in the matrix clause that indicates a cognitive state. In such contexts an assumption is being made about a possible later action or event which may or may not have taken place, and würde is being used in a primarily temporal sense to indicate futurity in a past context. The würde periphrasis is thus functioning essentially as the past of the future periphrasis with werden, which would be used if the matrix 
verb were in the present tense. Any elements of modal meaning in such contexts are carried primarily by the matrix verb rather than the würde-form, which is neutral in respect to the factuality of the event or action reported in the complement clause. Smirnova (2006, p. 134) gives the following example of this second variety in modern German:

(4) Mein Vater war so erschüttert, dass ich Angst hatte, er würde es für geschmacklos halten, jetzt wieder von Geld anzufangen.

contending that the synthetic preterite subjunctive hielte would not be acceptable in this context. Smirnova's analysis of the würde-construction as a marker of inferential evidentiality in such contexts is surely accurate, but there must nevertheless remain some doubt as to the validity of her assertion that this variety is wholly distinct from the first, where the würde-form substitutes for the preterite subjunctive. It is certainly the case that only the würde-form is acceptable in contexts where it has a purely temporal sense and there is no doubt that the event in question took place, as in examples (1)-(2), as is particularly evident where the matrix verb is wissen. However, it is not difficult to find examples where the preterite subjunctive is being used in precisely the same way with the matrix verb Angst haben, e. g.:

5) Man entließ die Sekretärin, sie schwieg dazu, weil sie Angst hatte, sie käme dann auf eine schwarze Liste, und ich auch, aus Angst mit zu fliegen.

(die tageszeitung, 11.12.2007)

In this example it would seem plausible to contend that käme is equally expressing an inference, and the secretary is keeping quiet on the basis of the evidence available to her. It would be difficult to establish objective criteria on the basis of which a distinction in meaning might be adduced between käme in example (5) and the würde-form as used in example (4) - or in example (6), with würde kommen in the complement clause:

6) Früher wurde eher von sportlichen Aktivitäten in der Schwangerschaft abgeraten. Der Grund: Man hatte Angst, dass es zu einer Verfestigung des Beckenbodens kommen würde, die bei einer Spontangeburt hinderlich wäre.

(Braunschweiger Zeitung, 25.07.2006)

It would appear that in practice the preterite subjunctive and the periphrasis with würde are being used with identical meaning in these examples, and it would be extremely difficult to pin down why one should be used rather than the other. In all of them there is an inferred fear, on the basis of available evidence, that an event might take place, but from the perspective of the present we are unsure whether this possibility actually materialized. We are thus not dealing simply with an expression of temporality, but one which combines this with modality in a way 
typical of verb forms involving future time. ${ }^{4}$ In such contexts the würde-form appear to be interchangeable in meaning with the synthetic preterite subjunctive, and the latter is freely used with verbs where this form is still commonly used, as is the case with käme. This is demonstrated by the fact that a search in the Deutsches Referenzkorpus ${ }^{5}$, from which examples (5) and (6) are taken, produced 14 instances of hatte Angst followed by a complement clause with käme, and 18 instances where it was followed by a complement clause including kommen würde.

Given these considerations we will not follow Smirnova $(2006,2007)$ in distinguishing discrete varieties of the würde-form but consider it as a single category capable of expressing meanings along a cline between temporality and (propositional) modality. In almost all its uses it would appear to have identical force to the synthetic preterite subjunctive, which it has effectively replaced in current usage for all but a few common strong and irregular verbs, with the only exception being those contexts which primarily involve temporality and the synthetic preterite subjunctive is excluded. This range of uses, from expressing present time hypotheses to futurity in a past context is parallelled by verb forms in many other languages, in particular the English would construction and the French conditional, cf. Comrie (1985, p. 75). In the case of the latter the range in function has long been recognized by the use of the two terms sconditionnelı and sfutur du passé to refer to it, (parallelling the distinction proposed for German by Jørgensen [1966] which was discussed above), with the former term referring to modal uses and the latter to temporal, cf. Vuillaume (2004). Indeed it is perhaps indicative that French accounts of German, as early as Fourquet (1970, p. 78), have tended to be precise in identifying both modal and temporal uses of the German würde-form. In terms of its morphology, the French form is clearly part of the indicative system, cf. Vuillaume (2004), whilst the würde-construction appears from its form rather to belong to the subjunctive paradigm, and it is perhaps this which has been at the root of the difficulty mentioned earlier of establishing the place of the construction in the German verbal system. As Fabricius-Hansen (2000, p. 83) points out, although Thieroff (1992) attempts to show how the würde-construction may be regarded as an indicative form, he is unable to show why it should then be able to substitute for the preterite subjunctive, i. e. be apparently equally part of the indicative and the subjunctive systems. However, an explanation for this might plausibly be sought in the fact that the interplay of futurity and propositional modality

4 In our view, both the periphrasis with würde and the synthetic preterite subjunctive are characteristically capable of expressing the range of modal meanings identified by Palmer (2001, pp. 8 f., 24-69) as spropositional, which he takes to encompass both epistemic and 5 These data derive from the subcorpus >Archiv der geschriebenen Sprache` in the Deutsches Referenzkorpus - DeReKo, accessible online at https://cosmas2.ids-mannheim.de/cosmas2-web/ faces/investigation/archive.xhtml (last accessed: 18.08.2016). 
is a well-known feature of languages, cf. Bybee, Pagliuca and Perkins (1991, 1994), since, ultimately, as Lyons (1977, p. 677) states, >Futurity is never a purely temporal concept $\iota$. In English, German and many other languages utterances with what is commonly called the sfuture tense s often have an epistemic rather than a temporal sense and denote possibility rather than futurity (or together with it), cf. Thieroff (2004), and it is frequently the subject of ongoing controversy between specialists in these languages whether such forms are to be considered as belonging to the tense system proper, or rather to the category of modality. In respect of English, for example, Huddleston and Pullum (2002, pp. 208-210) reject what they refer to as the straditional analysis` and do not recognize a future tense for English, and Palmer (2001, p. 170) says: »There are many examples of the use of what are generally regarded as future tenses to refer to probability«. Vater (1975) comes to a similar conclusion for German and considers the construction with the present tense of werden and an infinitive as modal rather than temporal, although, as Smirnova (2006, pp. 109-110) makes clear, most recent studies have held to the traditional view of this construction as a sfuture and thus as part of the tense system whilst acknowledging that it is frequently used with modal meanings, cf. also Kotin (2003, pp. 211-220), Szatzker (2002, pp. 45-47), Thieroff (1992, pp. 119-125), Welke (2005, pp. 367-377) and Zifonun et al. (1997, pp. 1699-1701, 1900-1902).

These uncertainties in respect of future tenses are clearly relevant to any account of the German würde-construction, which, as we have seen, exhibits a similar interpenetration of modal and temporal meanings. As Wolf (1995, p. 196) says:

»Die Fügung würde + Infinitiv [hat] ganz wesentlich eine temporale Funktion, obschon darauf hingewiesen werden muß, daß Futurisches, ganz gleich von welcher Zeitstufe aus, stets starke modale Komponenten hat, denn über die Zukunft lassen sich bekanntlich kaum sichere Aussagen machen, sondern lediglich Vermutungen anstellen.«

In a general comparative account of tense systems in language Comrie (1985, p. 75) makes clear that although many languages have a verb form which denotes past futurity, with these

»there is the particularly acute problem of future forms having modal as well as temporal values. Thus the English form would leave is probably more often than not used with modal meaning, whence its usual name conditional, but it can also be used purely temporarily.«

Such considerations would appear to be equally applicable to the German würde-construction in the verbal system of modern German, as already pointed out by Paul (1920, p. 153), although the traditional term >Konditional(is)< is no longer used to refer to it. The confusion about form and function which has bedevilled attempts to analyze it has a long history, and this is reflected in the various terms which have been used, cf. Thieroff (1992, p. 141). Nevertheless, in 
the light of these considerations it would not seem adequate to see it as exclusively - or even primarily - in terms of tense or modality, but, like the future with werden, as potentially pertaining to both. This is in essence the conclusion also reached by Kotin (2003, p. 180-182) who proposes the category >prognostic to account for this range of meaning. As he says (p. 181):

»Wenn wir nämlich die Prognostik als eine selbständige Kategorialfunktion annehmen, verwandelt sich die Diskussion über modale vs. temporale Zuordnung der behandelten Periphrase in den Henne-Ei-Streit, ist ja Prognostik ein unveräußerlicher Bestandteil der Prospektivität und zugleich der Epistemik.»

In our view, this represents the most convincing basis for understanding the place of the construction in the tense and mood systems of modern German, and we shall use it as a starting point from which to investigate the diachronic development of the construction in the early modern period.

\section{The origin and history of the würde- construction}

The würde-construction first appears towards the end of the Middle High German period, and detailed accounts of its history are to be found in Kotin (2003), Smirnova (2006) and Szatzker (2002). The formation of the construction is evident, since it is clearly a combination of the preterite subjunctive of werden with the infinitive, and it is thus in origin a subjunctive counterpart to the ingressive use of the past tense of werden with a present participle or infinitive found up to the sixteenth century, cf. Smirnova (2006, pp. 242-259). However, there is no full agreement on the reasons why it should have emerged or on its precise relationship to the periphrasis with the present indicative of werden which originally had ingressive/inchoative force but developed future meanings, in the course of time completely replacing the combinations of modal auxiliaries with the infinitive which had been used to express futurity in Old and Middle High German.

The first attested instances of the construction date from the first half of the fourteenth century and they occur in contexts which had previously been the preserve of the synthetic preterite subjunctive. Thus we find it in the apodosis of a 
conditional sentence for the first time in the gospel translation made for Matthias von Beheim in 1343, as given in >DWb $(29,256)$; cf. Kotin $\left(2003\right.$, p. 177) ${ }^{6}$ :

7) ob dise swigen, die steine worden schrîen (Luke 19, 40)

>If these should hold their peace, the stones would immediately cry out

In fact, although this has rarely been noted, the form is actually attested even earlier than this in the protasis of a conditional sentence, and in a clause parallel to one containing a synthetic preterite subjunctive, in Ottokar von Steiermark's >Österreichische Reimchronikı of about 1320, see >DWbく $(29,257)$ :

8) ob ir nû kæmet ûf ein hûs

und ouch immer wurdet phlegen,

sô müest ir iuch bewegen

unser aller, die hie sîn

sIf you came to a house and continued to stay in it, you would have to abandon all of us who are here

The same work also contains the earliest attestation of the form with the meaning of a future-in-the-past, cf. >DWb $(29,255)$ :

9) und swer ir îlen het gesehen,

der müeste des fürwâr jehen,

daz nie von kuniges kinde

wart gesehen alsô swinde

über velt gegangen,

dâ si wurd enphangen

von Arrogûn diu kunigin

sand whoever had seen her haste would have to say in truth that no king's child had ever been seen going so fast over fields to the place where the queen of Aragon would receive her

In these earliest examples the construction is essentially compositional, and its use could be explained as a need perceived ad hoc to express a hypothetical possibility combined with some kind of temporal relationship (appositely characterized as a »Folgerelation« by Smirnova [2006, p. 255 and passim]) more clearly

6 It is not until well into the $16^{\text {th }}$ century that the distinction between umlauted and nonumlauted vowels is noted with any degree of consistency, especially in Central German, cf. Ebert et al. (1993), p. 34-35; Guchmann/Semenjuk (1981), p. 137. Indeed, some of our corpus texts from the later $17^{\text {th }}$ century still fail to distinguish $<\mathrm{u}>$ and $<\ddot{\mathrm{u}}>$ ( or $<\dot{\mathrm{u}}>$ ). In such cases the fact that we are dealing with instances of the würde-form must be deduced from the context. 
than would be possible with the preterite subjunctive alone. This could even account for its use in the protasis in (8), as the two clauses of the protasis are not exactly parallel, given that the second, with wurdet phlegen, actually refers to a hypothetical event subsequent to that in the first clause.

However, these examples show that the periphrasis is used from its earliest attestations to express a combination of epistemic modality with a prospective time relationship. Welke (2005, pp. 449-488) presents a closely argued and convincing account of how the various uses of the form could have developed and are related to one another. He begins with the question which has not been resolved satisfactorily as to why, if the construction arose to express a future-in-the-past, it should be formed with the preterite subjunctive rather than the preterite indicative, parallelling the use of the present indicative of werden to express futurity which emerged during the same period. ${ }^{7}$ He proposes solving this question, cf. especially Welke (2005, p. 463), with the suggestion that the construction originally expressed a future possibility from the perspective of the past, as is the case in complement clauses dependent on nonfactive verbs such as glauben or meinen or verbs of saying. In such clauses the subjunctive would be expected rather than an indicative, and if the matrix verb is preterite, the then operative rule of the sequence of tenses would require a preterite subjunctive. The use of the form was then extended, cf. Welke (2005, p. 467), in a drift "von einer Konjunktivbedeutung zu einer reinen Tempusbedeutung" to clauses dependent on factive verbs such as wissen in order to express futurity in the context of past time with little or no modal implication. On the other hand, as he says (2005, p. 453): »Der Konjunktiv Präteritum des Futurs ist wegen der typischen Inferenz des Konjunktiv Präteritums auf Zukunft [...] mit dem einfachen Konjunktiv Präteritum synonym«, and thus the periphrasis with würde came also to be reinterpreted as semantically equivalent to the synthetic preterite subjunctive. The major function of the latter in ENHG was to express epistemic modality, cf. Ebert et al. (1993, p. 421), but it had also been used in OHG and MHG in contexts involving past futurity, cf. Paul (2007, p. 291) and Schönherr (2011). Indeed, as Szatzker (2002, pp. 177-179) shows, it is still commonly used in this function in the second half of the $17^{\text {th }}$ century, being almost equally frequent in her material as the würde-form, although, as she is able to demonstrate, this usage subsequently declines rapidly. It is thus plausible that the würde-periphrasis came to be preferred there in order to express the temporal element

7 Periphrases with the present and preterite tenses of werden were originally inchoative or ingressive in meaning, and more often contained the present participle rather than the infinitive, but at the latest by the ENHG period the form with the infinitive had become fully established to express futurity and had effectively replaced periphrases with the modal auxiliaries in this sense, cf. Ebert et al. (1993), pp. 391-394; Fleischer (2011), pp. 137-140; Guchmann/Semenjuk (1981), p. 137. 
more clearly, and this would certainly appear to be the case in the first attestations given as examples (7)-(9) above. However, it then came to encroach on other contexts which had previously been the exclusive preserve of the preterite subjunctive, especially those which involve a time relationship of some kind, notably in the apodosis of conditional sentences where it becomes much more frequently used in the ENHG period, cf. Smirnova (2006, pp. 305-313). As a result it came to be seen simply as an analytic alternative to the preterite subjunctive which could be preferred to it in certain conditions. In this way, Welke (2005) provides a coherent and plausible account of the possible semantic development of the construction, although he does not relate his theoretical reconstruction systematically to the attested historical records, incomplete as they are, and convincing as his account is as a reconstruction of the possible semantic development of the form, examples (3)-(5) above show clearly that the earliest records of the form exhibit the combination of temporal and modal senses which we have seen as characteristic for its use in modern German.

\section{The würde-construction in early modern German}

The periphrasis is used with increasing frequency through the ENHG period, especially from the early $16^{\text {th }}$ century onwards, cf. Ebert et al. (1993. p. 392) and Szatzker (2002, pp. 145-146). Szatzker notes that in her material some $55 \%$ of 33 occurrences involve primarily temporal meanings (future-in-the-past) in the second half of the $15^{\text {th }}$ century, but a century later over $70 \%$ from 42 occurrences are primarily modal, expressing a hypothetical possibility. Smirnova (2006, p. 242-328) gives a very detailed account of the development of the construction in ENHG in terms of its usage and semantics, but she does not provide any specific information about its comparative frequency, or the frequency or relative chronology of the various sub-meanings which she identifies, since she is primarily concerned with identifying the processes of its grammaticalization. However, given the divergences of opinion, the difficulty of establishing clear criteria for adducing grammaticalization and the fact that the concept itself is not uncontroversial, cf. Campbell (2001), this is an issue which would require much more extensive consideration than would be possible within the limits of the present paper, and we shall not pursue it further here beyond noting that by the middle of the $17^{\text {th }}$ century the periphrasis had clearly become established in a number of usages which had previously been the preserve of the synthetic preterite subjunctive, and we shall now proceed to an account of the development of the construction from 1650 onwards, on the basis of the material provided by the GerManC-corpus. 
The würde-construction occurs in total 806 times in the GerManC-corpus, and the distribution of the occurrences in terms of sub-period, region and register are shown in Table 1.

Tab. 1: würde in the GerManC-corpus

\begin{tabular}{|c|c|c|c|c|c|c|c|c|c|c|c|}
\hline & & DRAM & HUMA & LEGA & LETT & NARR & NEWS & SCIE & SERM & \multicolumn{2}{|c|}{ TOTALS } \\
\hline & NG & 2 & 4 & 34 & 7 & 10 & 1 & 3 & 4 & 65 & \\
\hline 1650 & WCG & 2 & 7 & 18 & 4 & 8 & 3 & 1 & 6 & 49 & \\
\hline- & ECG & 4 & 11 & 12 & 8 & 14 & 4 & 1 & 3 & 57 & 240 \\
\hline \multirow[t]{3}{*}{1700} & WUG & 2 & 3 & 8 & 0 & 7 & 6 & 1 & 0 & 27 & \\
\hline & EUG & 2 & 6 & 9 & 7 & 10 & 3 & 3 & 2 & 42 & \\
\hline & NG & 9 & 3 & 6 & 30 & 12 & 2 & 15 & 11 & 88 & \\
\hline 1700 & WCG & 15 & 8 & 8 & 6 & 11 & 0 & 5 & 1 & 54 & \\
\hline- & ECG & 17 & 12 & 14 & 25 & 6 & 11 & 0 & 7 & 92 & 328 \\
\hline \multirow[t]{3}{*}{1750} & WUG & 4 & 13 & 6 & 6 & 6 & 5 & 11 & 5 & 56 & \\
\hline & EUG & 2 & 2 & 6 & 14 & 2 & 3 & 5 & 4 & 38 & \\
\hline & NG & 6 & 0 & 14 & 9 & 2 & 5 & 4 & 2 & 42 & \\
\hline 1750 & WCG & 7 & 5 & 4 & 7 & 9 & 3 & 4 & 22 & 61 & \\
\hline- & ECG & 3 & 8 & 1 & 11 & 8 & 3 & 3 & 4 & 41 & 238 \\
\hline \multirow[t]{2}{*}{1800} & WUG & 7 & 4 & 12 & 6 & 6 & 6 & 5 & 7 & 54 & \\
\hline & EUG & 7 & 7 & 0 & 8 & 8 & 0 & 5 & 4 & 40 & \\
\hline \multicolumn{2}{|c|}{ Totals } & 89 & 93 & 152 & 150 & 119 & 55 & 66 & 82 & 806 & \\
\hline
\end{tabular}

There is a certain degree of variation in the overall frequency of the construction in the corpus in that it occurs almost equally often in the first and third periods, but there are rather more instances of its use in our second period, the first half of the eighteenth century. In the absence of further information it would be difficult at the moment to venture any clear explanation for this apparent surge in the usage of the construction, since there is no evident systematic correlation with register or regional differences, and we must simply assume that it is due to preferences of the individual authors in respect of style or expression. It is certainly the case that some corpus texts have a much larger number of conditional sentences than others. For example, the remarkable number of twenty-two occurrences of the construction in West Central German sermons in the third period is chiefly due to the fact that two of the texts present detailed account of 
the consequences which might follow if the hearers fail to behave as recommended by the person delivering the sermon. However, the most important conclusions to be drawn from these data are, first, that there is no substantial increase or diminution in the use of the construction over the period as a whole, and this would be corroborated by the data in the comparable study by Szatzker (2002). Secondly, there is no significant consistent regional variation in the occurrence of the construction. In this respect, our corpus data do not bear out the frequently voiced opinion of some prescriptivists in the later nineteenth century that it originated in South German and is characteristic of southern usage, cf. Brooks (2015) and Durrell (2007).

All the occurrences of the construction in the corpus were analysed by both co-authors independently and on the basis of this an agreed scheme of classification was devised which covered what emerged as its principal usages. These usages were mainly defined on the basis of the syntactic environment, as it was found that this provided a set of replicable criteria on the basis of which both coauthors could agree on how each instance could be appropriately classified. We attempted to achieve a more fine-grained analysis of the usages in semantic terms, e .g. by trying to identify the relative proportion of temporality or modality in particular examples. However, we found that it was not possible to reach consistent agreement about such classifications or to establish clear and replicable criteria by which finer semantic divisions could be identified satisfactorily. This is perhaps not wholly unexpected, given the inherent difficulty of making introspective judgements about diachronic data, cf. Sapp/Roehrs (2016, p. 96). We shall thus present the corpus data according to the following scheme of classification comprising the following six categories, which are illustrated by examples from modern German. The total number of attestations in the corpus is indicated in each case.

a) (15 attestations) purely temporal future-in-the-past, with the event having definitely occurred subsequent to the reference time of the past narrative, but before the present. This occurs prototypically in complement clauses after factive verbs, e. g.: Sie wusste, dass sie ihn erst nächste Woche wiedersehen würde, but other types of context are possible, e. g.: Sie hatte ein Treffen verabredet, das sie auf den Gipfel des Schneehorns führen würde.

b) (87 attestations) future-in-the-past in complement clauses dependent on non-factive verbs, such as Angst haben, glauben or hoffen (or nouns derived from such verbs), e. g.: Er hoffte, dass er Monika bald sehen würde. In these contexts we cannot necessarily infer that the event in question actually took place subsequent to the reference time given by the verb in the matrix clause. We are thus dealing with the kind of combination of a temporal relationship with epistemic meaning which we have seen as typical of so-called sfuture 
tenses . Welke (2005, p. 463) considers this usage to have been the origin of the construction with würde.

c) (44 attestations) future-in-the-past after verbs of saying, i. e. in reported speech. In these contexts, as in (b), there is a clear modal element, since, here too, no inference may be drawn as to whether the event in question actually took place, e. g.: Sie sagte mir, dass sie den Brief noch heute abschicken würde. In presentday standard usage the würde-construction in such contexts is in competition in the third person singular with the forms of Konjunktiv I, but this is a later development from the end of the eighteenth century, after the rule of the sequence of tenses ceased to apply, cf. Fernandez Bravo (1980, p. 99). This will be discussed further in section V.2.

d) (252 attestations) in the apodosis of conditional sentences: Wenn wir viel Geld hätten, würden wir nicht im Stadtzentrum wohnen. As we saw earlier, examples of this usage can be found from the earliest attestations of the würde-construction, and this has usually been attributed to the fact that the apodosis represents a hypothetical inference or consequence following from the condition given in the protasis, cf. Comrie (1986, pp. $80 \mathrm{f}$.): »The causal relation is from the protasis as cause to the apodosis as effect«. It is thus subsequent to it in time, which could favour the use of a verb form with the potential for future reference, cf. Welke (2005, p. 461) or Smirnova's `Folgerelation`. In this context the periphrasis with würde is thus from its earliest occurrence in competition with the synthetic preterite subjunctive which is the norm in the apodosis as well as the protasis in earlier stages of the language, cf. for MHG, Paul (2007, pp. 438-441). The major function of the latter is to express a hypothetical possibility, but as we have just seen, it can only express a temporal relationship by implication, in that it points to the possibility of an occurrence taking place after the relevant reference time.

e) (144 attestations) in the protasis of conditional sentences: Wenn ich das Fenster aufmachen würde, so könnte ein Vogel hereinfliegen. As we have seen, this usage is already attested in the early $14^{\text {th }}$ century, although this has not to our knowledge been noted previously, and it also occurs in Luther's writings, cf. Smirnova (2006, p. 320). Here too, since we are dealing with a hypothetical possibility, the periphrasis is being used in a context which had previously been the preserve of the preterite subjunctive. However, it is infrequent in MHG and ENHG, cf. Behaghel (1924, p. 245), and Smirnova (2006, p. 320) confirms that it is relatively uncommon in her material from the Bonn Corpus of Early New High German. As we shall see, this usage becomes more frequent in early modern German, but it comes to be severely stigmatized in the nineteenth century, cf. Durrell (2007). 
f) (264 attestations) to express a hypothetical possibility in other contexts, i. e. outside the prototypical framework of conditional sentences with a protasis and apodosis, especially, but not necessarily, in isolated main clauses, e. g. So etwas würde sie nicht machen. They may involve an explicit conditioning factor of some kind, for example with an adverbial, as in: Das würde ich an deiner Stelle nicht tun, or a condition given within the overall discourse context. However, it may simply be an imagined possibility or an assumption on the basis of the available evidence that something is likely to be the case, e. g. Sie würde ihn kaum im Stich lassen. These contexts, too, had previously been the preserve of the preterite subjunctive, cf. Behaghel (1924, pp. $237 \mathrm{f}$.) and Dal (2014, pp. 173-175), and in them, the würde-construction is semantically equivalent to the preterite subjunctive.

Table 2 gives the number of attestations for each of these categories in each of our chronological periods.

Tab. 2: Attestations of each category of würde in each period

\begin{tabular}{lcccc}
\hline & $\mathbf{1 6 5 0 - 1 7 0 0}$ & $\mathbf{1 7 0 0 - 1 7 5 0}$ & $\mathbf{1 7 5 0 - 1 8 0 0}$ & Total \\
\hline (a) future-in-the-past & 3 & 10 & 2 & $\mathbf{1 5}$ \\
(b) after non-factive verbs & 30 & 40 & 17 & $\mathbf{8 7}$ \\
(c) after speech act verbs & 19 & 9 & 16 & $\mathbf{4 4}$ \\
(d) conditional apodasis & 48 & 122 & 82 & $\mathbf{2 5 2}$ \\
(e) conditional protasis & 82 & 31 & 31 & $\mathbf{1 4 4}$ \\
(f) in independent clauses & 58 & 116 & 90 & $\mathbf{2 6 4}$ \\
\hline \multicolumn{1}{c}{ Total } & 240 & 328 & 238 & $\mathbf{8 0 6}$ \\
\hline
\end{tabular}

In the remainder of this section we shall investigate the development in the use of the construction in $17^{\text {th }}$ and $18^{\text {th }}$ century German in terms of this categorization. It may be noted that contexts involving a significant degree of temporality, i. e. (a) to (c), account for some $18 \%$ of the total, whereas $82 \%$ express a hypothetical possibility with a limited degree of temporality. In the course of the investigation we shall also pay specific attention to whether frequency variation can be linked to factors allied to register. 


\section{Purely temporal uses of the würde-construction}

The first three usage-types identified above have a clear temporal element, with the würde-form referring to an event occurring subsequent to a reference time in the past, but before the present. The first group includes only contexts which are purely temporal, i .e. where it is clear that the relevant event actually took place, e. g.:

10) Ich wust' es daß er noch würd' (ob wol spät) ankommen [...] (DRAM_P1_OMD_1657_Cardenio) ${ }^{8}$

In this usage, würde can occur with a perfect infinitive, but there is only one such instance in the corpus:

11) ich weis, daß er auch den Gedanken der Untreue nicht in sich würde haben aufsteigen lassen (DRAM_P2_OMD_1747_Schwestern)

We have deliberately defined this group in the most restrictive way to include only those cases where it is absolutely clear that no modal component is present and we may adduce a »reine Tempusbedeutung « in the sense of Welke (2005, p. 467) - in other words where we are dealing with an actual event or activity which took place after the past reference time, and not a possibility from the perspective of the past. This is by far the least frequent context in the corpus for the use of würde, with only fifteen occurrences, the majority of which are in complement clauses dependent on factive verbs or verbs of perception, in particular wissen and sehen, each of which account for five occurrences, with one instance after each of sich bekümmern, verheißen, vernehmen and versprechen. In only one example do we simply have an expression of a future-in-the past time sequence within a narrative of events, e. g.:

12) Diese Anstalt und Einrichtung des Kaysers sahe nicht ungerne, sondern war im Gegentheil recht angenehm, indem mir solches manche Gelegenheit und Ursache an die Hand geben wüde, diese und jene Veränderung anzustellen und dabey auszuuben. (NARR_P2_WMD_1750_Teutsche)

That the purely temporal use of the würde-construction is relatively infrequent should not be unexpected, despite the recent attention which has been paid to it

8 Data from the GerManC-corpus are cited using the file name, which gives some basic information about the text. In (10), for example, the file name indicates the register (DRAM = Drama), the period $(\mathrm{P} 1=1650-1700)$, the region of origin $(\mathrm{OMD}=$ Ostmitteldeutsch [East Central German]), year of publication or writing (1657), and the author and/or the title of the work, in this case, Gryphius' >Cardenio und Celinde`. 
in respect of modern German, since in practice this reflects the general observation by Comrie (1985, p. 75) which was referred to earlier and appears to be valid cross-linguistically, that verb forms expressing futurity in the past are rarely used without some element of modality being involved. In the light of the conclusions by Kotin (2003, pp. 180-182) mentioned above, it is not surprising that we find so few wholly unambiguous instances of purely temporal usage.

The variation in the occurrence of the würde-form in these contexts in respect of register can probably be attributed to the nature of writing in the individual register and the degree to which this may require reference to this particular time relationship, since it is most frequent in narrative texts, with five instances, and it does not occur at all in legal or humanities texts, or in newspapers. It occurs in roughly equal numbers in all regions, but there are differences between the periods with three instances from the first period, ten from the second, and only two from the third. However, no real significance can be attributed to this variation, since, aside from the very small numbers involved, the construction is widely used in this sense into the nineteenth century and beyond, cf. Szatzker (2002, pp. 139-157).

An open question for the moment is the extent to which the würde-form in this type of context is in competition with the preterite subjunctive, i. e. whether the latter can still be used to express futurity in a past context with no element of modality, as in earlier periods. Szatzker (2002, pp. 177-181) says that what she refers to as "Zukunft aus der Perspektive der Vergangenheit« is expressed by würde in $33.6 \%$ of cases between 1650 and 1700 and by the preterite subjunctive in $32.8 \%$, whilst a century later, between 1750 and 1800, the incidence of würde has risen to $46.5 \%$ with the preterite subjunctive at $11.6 \%$, with modal verb forms like sollte or wollte being used in most of the remaining instances. However, she does not differentiate systematically between contexts which are purely temporal and those with an element of modality (i. e. our groups [b] and [c], which are dealt with in the next section). Within the context of the present investigation it would have been difficult to establish the extent to which the preterite subjunctive was still used in such contexts, since this would necessitate a search for all occurrences of this form in the corpus and analysing these. However, a preliminary survey of verbs in complement clauses dependent on past forms of wissen, which is the most typical relevant context, resulted in only one instance (as against five with a würde-form), i. e.:

13) ich halte / er häte noch mehr gethan / so ihme solches nicht von seinem Hoffmeister wäre verbotten worden / welcher wol gewust hat / daß nichts daraus würde / dann er ware noch nicht zwantzig Jahr alt / und hatte kaum acht hundert Reichs-Thaler / baare Mittel (NARR_P1_OOD_1682_Winternaechte) 
and this example may be somewhat inconclusive since it includes würde, although it is here being used as a full verb.

\section{The use of the würde-construction to express potentiality in past contexts}

Our contexts (b) and (c) involve a modal element with the future-in-the-past time relationship, since the occurrence of the event in question is essentially a prognosis or supposition. It is presented as a possibility from the perspective of the past narrative, and there is no certainty as to whether it actually took place. In such contexts the würde-form typically occurs in a complement clause following a non-factive verb such as glauben, hoffen or meinen, or in reported speech.

Taking use after non-factive verbs and expressions first, we find würde attested 87 times in the GerManC-corpus, most frequently after hoffen, (ge)denken, (ver) meinen and related nouns, such as Hoffnung, Gedanke and Meinung. There is no evident variation in terms of region, but there are some differences in the frequency of occurrence over the time period which will be discussed later, together with usage in reported speech. The characteristic use of würde in clauses dependent on such non-factive verbs may be illustrated by the following examples:

14) Laura war der Stolz ihres Vaters, und die Seeligkeit ihrer Mutter, indem die leztere hofte, daß ihre Gesinnungen und Grundsätze in ihrer Tochter fortdauern, und auf ihre Enkel kommen würden.

(NARR_P3_WMD_1783_MoralischeErzaehlungen)

15) Dahero muthmasseten sie / die Vestung würde in letzten Zügen liegen / und avancirten des Dieners Wincken ohngeachtet.

(NARR_P2_NoD_1706_SatyrischerRoman)

(14) and (15) exemplify very clearly the cline between temporal and modal meanings of the würde-form in such complement clauses and the difficulty of assessing the extent to which each is relevant. In (14) the mother hopes that her daughter will accept her principles and pass them on to her grandchildren. This clearly lies in the future from the reference time provided by the time of the narrative, and the possibility that the daughter will indeed act as her mother wishes is a possibility which may not be realized (and, in a fictional narrative, the relationship of this event to speech time is irrelevant). In (15) the state of the fortress is an assumption which the actors are making at the time of the narrative. They will only be able to establish this with certainly after having moved forward, but the temporal element is less dominant and in this context the würde-form would appear to be 
semantically equivalent to the preterite subjunctive in a way which would not be the case with (14).

Nine examples have würde with a perfect infinitive, e. g.:

16) [...] giengen wir hinein / in Meynung / der Hauswirth wüde zu solchem Vorhaben allgemach haben auffschliessen lassen / [...].

(NARR_P1_WOD_1682_Feuermaeuer)

In this and similar examples the würde-form with the perfect infinitive expresses a complex time relationship which is in effect a future perfect in the past, ${ }^{9}$ whereby the event (the opening up by the housekeeper) precedes the reference time provided by the past narrative (our entry), but is a future event in respect of a further reference time in the remoter past. This time relationship can be expressed in modern English, e. g. »the housekeeper would have opened up for us«, or in French, with the conditionnel passé, e. g. »le concierge aurait ouvert la porte pour nous«, but in modern German such forms can sound »stilistisch häufig etwas umständlich«, cf. Zifonun et al. (1997, p. 1737) and according to Duden (2009, p. 539), they are »sehr selten« in such contexts, with the pluperfect subjunctive, e. g. »in der Meinung, der Hausmeister hätte für uns aufgeschlossen«, being preferred despite the potential ambiguity.

As with the purely temporal uses dealt with in the previous section, the question arises as to the extent to which the würde-form may be in competition with the preterite subjunctive in this type of context. For the reasons given earlier, we were only able to investigate this question in our corpus by surveying usage in complement clauses dependent on a selection of the relevant verbs, since an analysis of all occurrences of the preterite subjunctive was not practical. However, in clauses dependent on denken, glauben, hoffen, (ver)meinen and nouns derived from these, the preterite subjunctive is only used when it is simply a matter of a generalized hypothetical possibility, as in:

(17) [...] und zwar aus blossem Argwohn dieser schändlichen Huren / welche vermeinten / daß er ihrer mussig gienge und Andre buhlte.

(HUMA_P1_OOD_1689_Crain)

On the other hand, if any sense of temporality is present, as in example (14), then the würde-form is used. Our material thus indicates a potential distinction between the forms at this time, in that the preterite subjunctive is only used to express hypothetical possibility in these contexts, whereas the würde-form is employed

9 We are grateful to Maj-Britt Mosegaard-Hansen (Manchester) for her analysis of this time relationship and its parallel with the French >conditionnel passér. 
when a time relationship is involved, but may also be used in a primarily modal sense, as in example (15). Nevertheless, Szatzker (2002, pp. 177-181, 185-188) does report examples of its being used in this way in her data, although she emphasizes that this usage is »marginal « after 1750, and we have seen in our example (5) above that it is still current in modern German.

The second type of context in which past futurity inevitably involves a degree of modality is in reported speech. The typical form of such contexts in writing, as relevant for this study, is the reporting of a spoken assertion that an event would take place subsequent to the reference time of the narrative, which lies in the past, without there being any necessary implication that the event in question actually occurred. The form of such contexts will typically be a complement clause after a verb of saying, and the GerManC-corpus contains 44 instances of the würde-form being used in such contexts, e. g.:

18) etliche wolten es wurde ermeldter Marquis in den Landen umb dieselbe zu ombragiren verbleiben / oder der Hertzog von Jnspruck dahin geschickt werden / welches die zeit geben würd. (NEWS_P1_WOD_1662_Strassburg1)

There is a single occurrence of the würde-form being used with a perfect infinitive in reported speech, i. e.:

19) Theophilus ... sagte zu ihm / er wurde sonder zweiffel in einer so schlechten Herberg / und harter Ligerstatt wenig geruhet haben: es wär ihm dessen sehr leyd / doch hät er es fur dieses mahl nicht besseren konnen.

(NARR_P1_WOD_1689_Miranten)

As is the case with clauses dependent on non-factive verbs there is no evidence of any regional variation in the use of würde in reported speech. However, the construction is more frequent in both these contexts in certain registers - particularly in narrative prose, which accounts for $32 \%$ of the occurrences, both after nonfactive verbs (28 of 87 ) and in reported speech (14 of 44). The only other register with a noteworthy number of examples for these is the newspaper sub-corpus with 14 (non-factive) and 12 (reported speech). There are 10 instances after non-factive verbs in the dramas, humanities texts and letters, but relatively few records in other registers. The legal texts have one example, after a factive verb, and the science texts also only one, in reported speech. This variation can probably be plausibly ascribed to register-dependent variation in the frequency with which others' speech or thoughts is reported.

In modern German, the form of Konjunktiv I, i. e. werde, may be the preferred standard norm (rather than the würde-form) to indicate past futurity after some non-factive verbs and in reported speech with a matrix verb in a past tense, although in practice usage is variable and the subject of much uncertainty, cf. 
Duden (2009, pp. 523-539). However the GerManC-corpus has relatively few instances of Konjunktiv I in contexts of this kind, e. g.:

20) SOnntags hinderbrachte der Franzósische Ambassador dem Pabst ... wie daß nehmlich Se. May. [...] selbiges Geschäfft alles dem Pabst / solches beyzulegen / überlasse / und sich mit dem jenigen contentieren lassen werde / was ihm gutwillig von Chur Pfaltz / vermittelst Pabstl. Mediation / werde gegeben werden [...]. (NEWS_P1_WOD_1685_lindau)

werde is found only eight times in such contexts in our first period (1650-1700), and six of these are in a single text, a newspaper from Lindau from 1685, from which example (20) (which actually contains two instances) is taken. Limiting our investigation to third person singular forms, since other Konjunktiv I forms are identical to the indicative, we find that würde occurs 33 times in comparable contexts in this period, as against 8 for werde. In practice, werde is no more frequent later, with 5 instances between 1700 and 1750 and 6 between 1750 and 1800, as against 27 and 18 times respectively for würde. In effect, up to the end of the eighteenth century, our corpus texts do not show the Konjunktiv I form werde being used regularly to mark reported speech or following non-factive verbs, and usage effectively still adheres to the rule of the sequence of tenses, as in Early New High German, cf. Ebert et al. (1993, p. 455), whereby the tense of the matrix verb determines the tense of the subjunctive in the complement clause. These results are comparable to those of Fernandez Bravo (1980, p. 127), despite the fact that her data were taken from a relatively small number of literary texts, as she found only four examples of werde in Grimmelshausen's ıSimplicissimus as against $89 \%$ würde), six in Jung-Stilling’s `Heinrich Stillings Jugend ‘ (13.5 \%) and seven (15.2\%) in Moritz's >Anton Reiser «. In practice, only from the end of the eighteenth century does Konjunktiv I become a frequent (or even preferred) alternative in these contexts. Nevertheless, literary usage seems to have changed rather rapidly thereafter, since Fernandez Bravo (1980, p. 107) found that werde and würde were equally frequent in Goethe's novel >Die Wahlverwandtschaften of 1809. Otherwise, the preterite subjunctive is the most usual form in our corpus material in reported speech after a matrix verb of saying in the past tense, e. g.:

21) Als ich ihm sagte, daß die Gebåude da vor uns das Seraglio des Großherrn zu Constantinopel wären (NARR_P3_NoD_1786_Muenchhausen)

A search of all occurrences of sagen in the past tense followed by reported speech yielded no instances where the preterite subjunctive in the dependent clause had any sense of past futurity, and it would appear that such a temporal relationship in these contexts can only be expressed by the use of an appro- 
priate auxiliary, i. e. the würde-form or, in the latter part of the period, the Konjunktiv I form werde.

\section{3 würde in conditional sentences}

As seen in section IV above, some of the earliest attestations of the würde-form are in hypothetical conditional sentences, and in these it is essentially from the outset a periphrastic alternative to the synthetic preterite subjunctive which was the norm in both the protasis and the apodosis in MHG, cf. Paul (2007, pp. 438-441). As we saw in examples (7) and (8), würde appears in both contexts from the $14^{\text {th }}$ century, and it becomes more widely used in the course of the ENHG period, so that by the sixteenth century it has become widespread in the apodosis, although less frequent (if by no means unknown) in the protasis, cf. Ebert et al. (1993, p. 421). However, no previous studies have provided precise extensive data on the relative incidence of the form in the two parts of conditional sentences up to 1650, since neither Smirnova (2006) nor Szatzker (2002) treat these contexts separately, and thus it is not clear to what precise extent the periphrasis with würde was coming to replace the synthetic preterite subjunctive in conditional sentences by the seventeenth century, nor whether there was a marked difference in usage between protasis and apodosis.

Of the 806 occurrences of the würde-construction in the GerManC-corpus nearly half (396) are in conditional sentences, and these thus account for a significant proportion of its usage during this period. Of these instances, nearly two-thirds (252, i. e. $64 \%$ ) are in the apodosis and just over a third (144, i. e. $36 \%)$ are in the protasis. There are no marked regional differences in the occurrence of the form, but there is considerable variation in terms of register and chronology, as shown in Table 3.

Tab. 3: würde in the protasis and apodosis of conditional sentences

\begin{tabular}{llcccc}
\hline & & $\mathbf{1 6 5 0 - 1 7 0 0}$ & $\mathbf{1 7 0 0 - 1 7 5 0}$ & $\mathbf{1 7 5 0 - 1 8 0 0}$ & Total \\
\hline DRAM & Protasis & 2 & 0 & 0 & $\mathbf{2}$ \\
& Apodosis & 3 & 23 & 14 & $\mathbf{4 0}$ \\
\multirow{3}{*}{ HUMA } & Protasis & 3 & 2 & 1 & 6 \\
& Apodosis & 15 & 20 & 10 & 45 \\
\multirow{2}{*}{ LEGA } & Protasis & 67 & 19 & 20 & $\mathbf{1 0 6}$ \\
& Apodosis & 5 & 5 & 4 & $\mathbf{1 4}$
\end{tabular}


Tab. 3 (continued)

\begin{tabular}{llcccc}
\hline & & $\mathbf{1 6 5 0 - 1 7 0 0}$ & $\mathbf{1 7 0 0 - 1 7 5 0}$ & $\mathbf{1 7 5 0 - 1 8 0 0}$ & Total \\
\hline \multirow{2}{*}{ LETT } & Protasis & 1 & 1 & 0 & $\mathbf{2}$ \\
& Apodosis & 7 & 28 & 18 & $\mathbf{5 3}$ \\
\multirow{3}{*}{ NEWS } & Protasis & 4 & 3 & 1 & $\mathbf{8}$ \\
& Apodosis & 7 & 12 & 5 & $\mathbf{2 4}$ \\
\multirow{3}{*}{ SCIE } & Protasis & 4 & 3 & 1 & $\mathbf{8}$ \\
& Apodosis & 1 & 4 & 3 & $\mathbf{8}$ \\
\multirow{3}{*}{ SERM } & Protasis & 1 & 1 & 2 & 4 \\
& Apodosis & 4 & 19 & 8 & 31 \\
\multirow{2}{*}{ Total } & Protasis & 0 & 2 & 6 & $\mathbf{8}$ \\
& Apodosis & 6 & 11 & 20 & $\mathbf{3 7}$ \\
& Protasis & $\mathbf{8 2}$ & $\mathbf{3 1}$ & $\mathbf{3 1}$ & $\mathbf{1 4 4}$ \\
& Apodosis & $\mathbf{4 8}$ & $\mathbf{1 2 2}$ & $\mathbf{8 2}$ & $\mathbf{2 5 2}$ \\
\hline
\end{tabular}

Table 3 shows a number of interesting developments which have not been previously noted, in particular the striking extent of the use of the würde-construction in the protasis in legal texts, with nearly half of these being in clause initial position. However, after 1700 there is a marked decline in the use of würde in the protasis in all registers, although it is still more frequent in legal texts than elsewhere, whilst there is a notable increase in the frequency of würde in the apodosis. We can now proceed to examine each of these in more detail.

Example (22) represents a typical instance of the use of würde in the protasis of legal texts:

22) Jedoch / da ein Patient/ auf Bezahlung des Apotheckers / seine Recepta fordern wurde / soll er ihme die verfolgen zu lassen schuldig seyn (LEGA_P1_OOD_1700_Gesetznuernberg)

The protasis involves the statement of a generalized possible case, which is followed by an apodosis containing a modal verb in the present indicative, as in example (22), or another modal construction such as the so-called smodal infinitives, as will be illustrated in example (24) below. The apodosis characteristically expresses an obligation on the part of the party to the legal process to follow a particular course of action or permission for that party to do something should the relevant condition arise. 102 (i. e. $96 \%$ ) of the 106 occurrences of würde in the protasis in legal texts follow this pattern, with a modal verb or other modal construction in the present tense in the apodosis, and its force can clearly be subsumed under the general heading of >prognostic 
semantically very close to sollte when this is used in the protasis of conditional sentences to signal a tentative possibility, and in such contexts, which are quite close to open conditions, this also typically occurs with the present indicative in the apodosis, cf. for modern German, Zifonun et al. (1997, pp. 1893 f.).

As just mentioned, in legal texts the würde-form occurs frequently in clauseinitial position in the protasis of conditional sentences. To our knowledge, studies of German of this period have not previously noted this, possibly because of the traditional focus on literary texts rather than those in other registers, but our corpus data show it to be very characteristic of legal texts (which in our case are primarily legal codes), amounting to 40 (i. e. 38 \%) of all the attested instances of würde in the protasis of conditional sentences in this register. In general, they follow the same pattern as other occurrences of protases with würde, in that the würde-clause appears to express a tentative possibility (which might even imply a hope that the particular criminal activity would not occur), and the following apodosis contains a modal verb or another modal construction in the present indicative which gives the consequence if such a possibility were actually to occur, cf.:

23) Wurde auch jemand eine ledige Dienst-Magd, die sonsten ihre Ehre unbescholten, beschlaffen, die soll er zu der Ehe nehmen, oder aber, da er sich dessen verweigern würde, ihr einen gebührlichen Brautschatz nach der Magd Eltern Vermögen geben. (LEGA_P3_NOD_1757_Rostock)

24) Wurde aber in dem Inquisito die vollige Tortur zu vollziehen seyn / so ist derselbe erstlichen zu erinnern / womit er lieber in der Güe / und unerwartet der bevorstehenden Schärffe die unverfalschte Warheit bekenne.

(LEGA_P2_WOD_1711_Halsgericht)

Example (23) contains an example of clause-initial würde as well as an instance of würde in a parallel protasis introduced by the conjunction $d a$, whilst the apodosis of example (24) provides an instance of a modal infinitive construction in the present indicative rather than a modal verb.

Protases with initial würde are almost exclusively limited to legal texts in our corpus, with only six instances in other registers, of which five have a second person plural subject. One of these is in a scientific text of 1780 from Ansbach and four in a sermon of 1774 from Frankfurt, whilst one, in a sermon of 1715 from Zerbst, has würde co-ordinated with a preceding wollte, i. e.: Wolte und würde man [...]. With these few exceptions, this construction is clearly a special feature of legal language, and it has the appearance of a conventional formula which may possibly have originated in chancery usage. However, we are not aware of it having been noted in such texts in earlier periods - it is mentioned neither by Szatzker (2002) nor Smirnova (2006) - and, as Table 3 shows, its occurrence is much reduced in legal texts after 1700. The fact that it is still more frequent there 
than in other registers may reflect the conservatism of legal language which has been noted for other linguistic features, cf Durrell (2014, pp. 16-17) in respect of weak adjective endings. Nevertheless, it may be noted that the construction is by no means unusual in modern usage, and can still occur in similar legal or quasilegal contexts, although it is not limited to these, e. g.:

25) Würde die Stadt diese Dienstleistungen selbst erledigen, müsste sie für das Personal auch Tarifsteigerungen zahlen. (Braunschweiger Zeitung, 09.01.2013) ${ }^{10}$

Table 3 shows that würde is infrequent in the protasis outside legal texts, and its use in this context decreases markedly in all registers in the course of the $18^{\text {th }}$ century. We can perhaps consider this in conjunction with the increase in the use of würde in the apodosis of conditional sentences, since whilst this context accounts for $20 \%$ of the total occurrences of the form in our first period, this proportion increases to $37 \%$ in the second period and $35 \%$ in the third, as in the following examples:

26) Gewißlich wurden es die General Staaten von Holland / die Cantonen in der Schweitz / und alle Italianische Fursten / fur eine schlechte Glücks-Bedeutung dieses jünsten Cometens annehmen / so er ihnen / an ihrem formidablen Herrn Nachbarn / einen solchen Augustum, und eine Lilie zur Glucks-Blum / prognosticirte. (SCIE_P1_OOD_1681_CometenGespoetts)

27) Ich meines Orts bekenne meine Furchtsamkeit / würde mich auch nimmermehr entschliessen / Mortangs seinem Ansuchen zu folgen / wofern ihr nicht in meiner Gesellschafft den halben Theil der Gefahr mit auff euch nähmet. (NARR_P2_OMD_1708_Affecten)

28) Ja, wenn Du sagtest, Du wolltest mein Guelfo nicht seyn, mich denn zum Grabe trugst, itzt noch, dann wurdest Du mir einen Liebesdienst thun.

(DRAM_P3_NOD_1776_Zwillinge)

Dal (2014, p. 175) claims that this pattern, with a preterite subjunctive in the protasis and würde in the apodosis, has become the "normale Form « of conditional sentences by the eighteenth century. Whilst it is true that its frequency increases during the period covered by the GerManC-corpus, especially in the $18^{\text {th }}$ century, as it is attested 40 times in our first period, 104 times in the second and 75 times in the third, the corpus data overall do not support her claim, since the pattern with a preterite subjunctive in both protasis and apodosis is still the most frequent form of conditional sentences throughout the period in question. To illustrate this we can take a sample from the corpus of those sentences in

10 Example taken from the DeReKo-corpus. 
which the protasis is introduced by one of the most frequent conditional conjunctions, i. e. wenn, wann and wofern, (since searching in the corpus for conditional sentences which lack a conjunction is impractical). As shown on Table 4, 129 of 172 such conditional sentences (i. e. $75 \%$ ) in our first period, 146 of 240 (61\%) in our second and 169 of 264 (67\%) in our third period have the preterite subjunctive in both clauses, as opposed to $15 \%, 32 \%$ and $23 \%$ respectively with a preterite subjunctive in the protasis and würde in the apodosis.

Tab. 4: Verb forms in conditional sentences

\begin{tabular}{lcccc}
\hline & $\mathbf{1 6 5 0 - 1 7 0 0}$ & $\mathbf{1 7 0 0 - 1 7 5 0}$ & $\mathbf{1 7 5 0 - 1 8 0 0}$ & Total \\
\hline $\begin{array}{l}\text { preterite subjunctive in protasis and } \\
\text { apodosis }\end{array}$ & 129 & 146 & 169 & $\mathbf{4 4 4}$ \\
$\begin{array}{l}\text { protasis: pret. subj. } \\
\text { apodosis: würde }\end{array}$ & 25 & 76 & 57 & $\mathbf{1 5 8}$ \\
$\begin{array}{l}\text { protasis: würde } \\
\text { apodosis: pret. subj. }\end{array}$ & 17 & 14 & 14 & 45 \\
$\begin{array}{l}\text { würde in protasis and apodosis } \\
\quad \text { Total }\end{array}$ & 1 & 4 & 2 & 7 \\
& 172 & 240 & $\mathbf{2 4 2}$ & 654 \\
\hline
\end{tabular}

These results are markedly lower than those reported by Szatzker (2002, p. 143), since in her data $41 \%$ of apodoses had the würde-form between 1650 and 1700 and $42.1 \%$ from 1750 to 1800 , but this may be due to her having a rather smaller corpus available which was made up of texts from a more restricted selection of registers. However, this variation is consistent with the view that the two forms are already seen as semantically equivalent in expressing potentiality in conditional constructions in this period, which naturally leads to the question why würde might be preferred to the synthetic form. Behaghel (1924, p. 244) voices the supposition that the würde-construction might have been preferred with verbs whose preterite subjunctive is not formally distinct from the preterite indicative. However, this is not the case in Szatzker's (2002, p. 164) material from the $17^{\text {th }}$ and $18^{\text {th }}$ centuries, and the same is true in the GerManC-corpus. Indeed, in $71 \%$ (i. e. 180 of 252) of the apodoses in the corpus which contain würde it occurs with a strong or irregular verb which has a clearly marked synthetic preterite subjunctive, e. g.:

29) Wenn es in der Nacht einem furchtsamen Menschen begegnete / so würde er das Creutze vor sich schlagen. (DRAM_P1_OMD_1683_Masaniello) 
These cases even include sein and haben, where modern usage would favour the use of the synthetic preterite subjunctive over the würde-form in the apodosis of a conditional sentence. However, our data contain 50 occurrences of würde sein and 32 of würde haben in this context, e. g.:

30) Denn, wenn derselbe etliche 1000 mahl weiter, biß in den Bezirck des nechsten Fixsterns versetzet werden sollte; so würde gewiß nicht das geringste mehr davon zu sehen seyn. (SCIE_P2_NoD_1744_Cometen)

31) Wenn wir immer ein offenes Herz hä ten das Gute zu geniessen, das uns Gott fur jeden Tag bereitet, wir würden alsdenn auch Kraft genug haben, das Uebel zu tragen, wenn es kommt. (NARR_P3_OMD_1774_Werther)

Furthermore, würde is used on 33 occasions with a following perfect infinitive in the apodosis of a conditional sentence, i. e. as a pluperfect subjunctive to express a hypothetical or counterfactual condition, a usage which is now rare, cf. Zifonun et al. (1997, p. 1737), e. g.:

32) Hatte ich eure Zuneigung ehe gewust / so würde ich keinem andern lieber / als euch / meine Tochter gegeben haben. (DRAM_P2_NoD_1707_Schaeferspiel)

33) Wer weiß, was geschehen seyn wurde, wenn die Menschen im Stande der Unschuld blieben wären? (NARR_P2_OMD_1738_LebensBeschreibung)

The würde-construction is thus widely used in this period in conditional sentences, but it is difficult to identify any systematic semantic distinction from the preterite subjunctive, which is in practice still used more widely, overwhelmingly so in the protasis but also in the apodosis, as in the following typical example:

34) An manchen Orten werden naturliche Abfalle in den Flussen angetroffen / daruber der Strohm zwischen und über Klippen so entsetzlich hinab schiesset / daß entweder die Schiffe mit Gütern und Leuten Augenscheinlich zu Grund und Trümmeren giengen / wenn sie darüber hinab setzeten.

(SCIE_P2_WOD_1720_FangSchlaeussen)

It is certainly the case that the würde-form becomes rather more frequent in the apodosis, but it is still less frequent there than the synthetic preterite subjunctive, and it is not clear what motivation there might be for some writers to have preferred it. The pattern of the preterite subjunctive in the protasis and würde in the apodosis is one which later grammarians prescribe as >correct`, cf. Durrell (2007), and as will be discussed later, it is possible that their prescription was based on a subjective assessment of what had been developing towards a usage norm during this period. However, it was still not the dominant usage by 1800 , and the data from the GerManC-corpus up to then points to a relatively unsystematic alternation between competing forms. 


\section{The würde-form expressing a hypothetical possibility in other contexts}

The final context in which the würde-form occurs in our corpus data is in isolation, outside canonical conditional sentences, to express a hypothetical possibility. This may involve a condition expressed otherwise than by a subordinate protasis clause, for instance by an adverbial, with sonst as a very characteristic example, e. g.:

35) Das beste / das der Correspondent gethan / ist / daß er die Herren mit seinen Gedancken nicht länger aufhaltet / sonst würde er ihnen zu weit in ihr Amt greiffen / weil ihr Thun ist / die Leser alle Wochen etliche Minuten aufzuhalten. (NEWS_P2_WOD_1722_zuerich)

but it can also be simply an imagined possibility or an assumption on the basis of the available evidence that something is likely to be the case, e. g.:

36) Was offt kein Tyranne durch tausend Martern von jemanden erzwingen wurde; das vollziehet ein Herkules dem Willen einer schönen Omphale ein Gnügen zu thun.(HUMA_P2_OMD_1729_Biedermann)

In practice this is the most frequent type of context in which the würde-form is found in the GerManC-corpus, accounting for about a third of all occurrences (264 of 806), and in these contexts, as in conditional sentences, it would appear to be semantically equivalent to the preterite subjunctive. They already account for $24 \%$ of the total occurrences of würde (58 of 240) in the second half of the $17^{\text {th }}$ century and become even more frequent in the $18^{\text {th }}$ century, comprising $35 \%$ (116 of 328) of the total instances of würde between 1700 and 1750 and $38 \%$ (90 of 238) in the latter half of the century. In this case, the corpus material does not show any marked correlation between the use of the construction and region or register.

As with the use of the würde-construction in the apodosis of conditional sentences it does not appear to be the case that it is preferred to the preterite subjunctive in these contexts because of the homophony between the preterite indicative and preterite subjunctive forms of many verbs, especially weak verbs, since in $69 \%$ of the occurrences of würde in these contexts (181 of 264) it is used with a strong or irregular verb with a morphologically distinct preterite subjunctive, e. g.:

37) Und ohne die Sorge, die man selbige zu überwinden tragen muß, würde man viele Mißrechnungen in dieser Materia finden. (SCIE_P2_WOD_1741_Erden) 
As with usage in the apodosis of conditional sentences, a substantial number of these occurrences of würde involve sein (46 times) and haben (31 times), where the würde-construction is quite unusual in present-day usage, cf. Bausch (1979, p. 215), e. g.:

38) Es würden keine andre Leute als Turcomans seyn / deren Gewehr nichts als ein Säbel und eine Lantze ... (NARR_P2_NoD_1715_Africa)

39) Drittens wurde die Jugend hiervon beÿ Erlehrnung der lateinischen oder fremden Sprachen ohne derselben gar keinen Nutzen haben.

(LETT_P2_OOD_1734_Antesperg)

Examples with a perfect infinitive, i. e. with the force of a pluperfect subjunctive expressing counterfactuality are also quite frequent, with 30 instances in the corpus (26 with haben and 4 with sein), e. g.:

40) Das würden sie mir übel gedankt haben. (DRAM_P3_WMD_1787_Verbrechen)

41) Aus diesen Gräbern haben die neuen Italianer die halb vermoderten Reste hervorgezogen, nnd [sic.] der edlen Bau-Kunst Regeln davon abgesehen, welche vielleicht ohne vorher erlittenen Schaden nicht wüde in Ordnung gebracht seyn worden, nachdem man bereits in den morgenländischen Theilen des Romischen Reichs angefangen, wo nicht sie gantzlich aus dem Geschicke zu bringen, doch ihre Mannlichkeit mit überflußigen Zierrathen zu verstellen.

(SERM_P2_OMD_1715_Beerdigung)

Again such usage, if not strictly ungrammatical, is no longer current in modern usage, cf. Weinrich (2003, pp. 247 f.).

In these contexts, too, we were unable to establish any significant distinction in meaning between the periphrasis with würde and the synthetic preterite subjunctive. Although, again, it was impractical to attempt a comprehensive assessment of all occurrences of the latter in the corpus, it was clear from a sample survey that it was used freely during this period to express a hypothetical possibility, as is the case in modern German, e. g.:

42) Es stünde mir auch übel an / aus der Stadt in ein Castel zuweichen / da mein Befehl und meine Gegenwart noch das meiste operiren mussen.

(DRAM_P1_OMD_1683_Masaniello)

Similarly, the preterite subjunctive of haben and sein is commonly used with a past participle to express counterfactuality, e. g.:

43) Gerne hätte er sich die heitere Miene eines Mannes von der Welt gegeben. Aber es gieng nicht an. (HUMA_P3_OOD_1774_Emil) 
There would not appear to be any difference in terms of temporality or modality between the synthetic forms in these examples and the periphrasis in examples (35)-(41), and we may justifiably conclude that the two forms are semantically equivalent in such contexts.

\section{Summary: würde + infinitive in seventeenth and eighteenth century German}

We have shown in our foregoing account how the data from the GerManC-corpus provide a more detailed and more differentiated description than had previously been possible of how the use of the periphrasis with würde developed during the crucial period in the history of German when a standardized written variety was being established, and we were able to critically examine previous findings on the basis of a wider and more representative body of material. Essentially, we could demonstrate that the construction was fully established in the tense and mood system of German by the second half of the seventeenth century, in most contexts in variation with the synthetic preterite subjunctive which had been the most frequent form to express the relevant combinations of temporality and modality to the end of the MHG period.

In brief, our findings appear in agreement with our initial assumption that the uses of the würde-construction can only be adequately accounted for by considering it, like the future with werden, as a >prospective` or >prognostic ‘ form which may potentially pertain to both modality and tense, with the extent to which either is prominent ultimately depending on the wider discourse context. We found, first, very few examples - 15 of 806, i. e. fewer than $2 \%$ of occurrences of the construction - where we felt confident in assessing its usage to be wholly temporal, i. e. clearly expressing a future in the past with every indication that the event in question actually occurred. It would thus appear that this usage, which Thieroff (1992) assigned to the indicative system, is relatively marginal at this time, despite the fact that, as we saw in example (9), one of the earliest attestations of the construction in the $14^{\text {th }}$ century has this meaning. It is more widely found in the corpus in other contexts where there is a relatively clear expression of temporality, i. e. in complement clauses dependent on non-factive verbs or speech act verbs, but in these an element of modality is present since no inference may necessarily be drawn that the event in question did actually take place. Nevertheless, we were unable to find any occurrences of the synthetic preterite subjunctive in these contexts, which would suggest that there may be a clear preference for the periphrasis in contexts where the temporal relationship needs to be emphasized. 
These contexts together also constitute a relatively small proportion of the attestations of the construction in our corpus, i. e. just over $16 \%$ (131 of 806), which means that it occurs most often in conditional contexts, either in the apodosis or, less frequently, the protasis of canonic conditional sentences, or in isolation to express a hypothetical possibility. In all these contexts it functions as an analytic alternative to the synthetic preterite subjunctive, which is the inherited verb form with the capability of expressing such modal meanings, and the semantic equivalence of these forms which had emerged during the ENHG period has persisted into modern German. Smirnova (2006, 2007) sees its origin in the spread of the construction from the apodosis, where it clearly emphasizes a consequence (in her term, a >Folgerelation`) following on from the condition stated in the protasis, and this usage clearly originated in the ability of the construction to express future time, parallelling the development of future meanings by the periphrasis with the present tense of werden with the infinitive. She is supported in this view by the fact that in her ENHG data, taken largely from the Bonn Corpus of Early New High German, the würde-construction occurs predominantly in the apodosis of conditional sentences, and she says of its occurrence in the protasis and in isolation (Smirnova 2006, p. 321 and 2007, p. 33): »Solche Belege sind im von mir untersuchten Korpus noch sehr selten, was von einer erst einsetzenden Entwicklung zeugt«. If that is the case, though, the development would appear to have proceeded very rapidly, since in our first period, which comprises the half-century immediately following the conventional end of the ENHG period in 1650, about a quarter of the total attestations of würde (58 of 240 , i. e. $24 \%$ ) are in isolated clauses expressing a possibility, and over a third (82 of 240 , i. e. $34 \%$ ) are to be found in the protasis (as against 48 occurrences, i. e. $20 \%$, in the apodosis), although, as we have seen, a good proportion of these are in what appears to be a rather specialized usage in legal texts. Nevertheless, as illustrated earlier, one of the first attestations of the construction is in the protasis of a conditional sentence, and it would seem possible that a more broadly based sample of ENHG usage, including texts from a number of registers, could show that the construction was more frequent in such contexts than appears from the data in Smirnova (2006, 2007).

In our data, then, the würde-construction is clearly most frequent in contexts where it is semantically equivalent to the preterite subjunctive and it is thus in direct competition with that form. As mentioned earlier, the question thus arises of why the periphrasis might be preferred. A frequent supposition, already voiced by Blatz (1895, 1, p. 569), but also clearly stated by Behaghel (1924, p. 244), has been that the würde-construction came to be used primarily with those verbs whose preterite subjunctive was not formally distinct from the preterite indicative, in particular all weak verbs. However, Szatzker (2002, p. 164) found that this 
was not the case in her data from this period, in that würde often occurred with those strong or irregular verbs whose synthetic preterite subjunctive has a form which is distinct from the preterite indicative, and we have seen that the same is true in our data from the GerManC-corpus, in particular in the apodosis of conditional sentences and when expressing a hypothetical possibility in isolated clauses. With reference to this issue, Fleischer (2011, p. 142) says:

\begin{abstract}
»Bei der Entwicklung der würde-Periphrase ist die Frage besonders interessant, in welcher Relation die hier besprochenen semantischen Verschiebungen [...] und der morphologische Faktor stehen: Sind die nicht mehr eindeutigen Konjunktiv-II-Formen Auslöser oder eher ızufälliger Nutznießer` der semantischen Entwicklung? Um diese Frage zu beantworten, wären Untersuchungen nötig, zu welchem Zeitpunkt welche Verben in welcher Verwendung der würde-Form auftreten: Wenn sich herausstellt, dass sich die würde-Periphrase zunächst vor allem bei schwachen Verben [...] ausdehnt, liegt die Annahme nahe, dass die Morphologie eine entscheidende Rolle spielt. Zeigt sich dagegen, dass sich die würdePeriphrase bei allen Verben mehr oder weniger gleichzeitig ausbreitet, so spricht dies eher dafür, dass die semantischen Veränderungen die Hauptrolle spielen.«
\end{abstract}

It seems clear from our findings on the basis of the data from the GerManC-corpus that morphological factors did not play a decisive role in the emergence and spread in usage of the form. Indeed, the supposition that this might have been the case seems to rest primarily on what has become the norm in modern usage, where the synthetic form is used in particular with the most frequent strong and irregular verbs and the würde periphrasis in other cases, especially where there is homonymy between the forms of the preterite subjunctive and preterite indicative, cf. Bausch (1979). However, it would seem equally difficult to identify any plausible semantic motivation why the würde-form might have been preferred, given the degree of semantic equivalence between the competing forms in the $17^{\text {th }}$ and $18^{\text {th }}$ centuries. Szatzker (2002, p. 77) suggests that würde was initially preferred if some expression of temporality was involved, i. e. in cases where »es zunächst noch kompositionell auszulegen ist und eine stark zukunftsgerichtete Potentionalität bezeichnet«. Our findings in respect of usage in complement clauses dependent on factive and non-factive verbs, and in reported speech, could be considered to bear this out. Fritz (2000, p. 187) says in this context:

»Es ist zu erwarten, dass das Auftreten von würde mit Infinitiv Bedeutungen erreichen kann, die durch den Konjunktiv allein nicht erzielbar sind. Deshalb müsste der Konjunktiv II sich als eine semantisch schwächer determinierte `Ersatzform` von würde mit Infinitiv erweisen und nicht umgekehrt."

and this suggestion would appear attractive. Although the preterite subjunctive had been used previously in all the contexts in which the würde-construction came to compete with it, the latter does emphasize a temporal relationship in a 
way which is not possible for the synthetic form. Thus, it would not seem implausible to suggest that speakers might initially have had recourse to the periphrasis because they wished to express temporality together with modality more explicitly, and that the periphrasis enabled them to do this more clearly than was felt possible with the synthetic preterite subjunctive, and the sense that the latter had a distinctive meaning was lost. Similar factors have been adduced in conjunction with the emergence of periphrastic tenses more generally, as well as in the drift from synthetic to analytic structures which has characterized the history of many Indo-European languages, cf. Samuels (1972, pp. 82-84). Certainly, the growing tendency to prefer the würde-form in the apodosis which we have observed in our data, although it was never an absolute rule, could be taken to support this proposal, since it is precisely in the apodosis that the notion of a future consequence is very clear.

This also may provide a clue to the origin of the prescriptions which came to be associated with the construction in the nineteenth century. A principal aim of prescriptive endeavour is the elimination of variation and the stigmatization of those competing forms which are deemed to be incorrect, with this aim being motivated in large part, as Watts (2011) has shown, by what he terms the smyth of linguistic homogeneity`, i. e. the notion that all languages have a spure which is invariant and unchanging, and which needs to be established and prescribed as correct usage, cf. Elspaß (2014) with reference to nineteenth century Germany. As they had become semantically equivalent in almost all contexts, the würde-construction and the preterite subjunctive could not both be tolerated, since prescriptivists consider it axiomatic that no forms in a language can be exact semantic equivalents. A distinction thus needed to be created, as recognized by Brooks (2015), and preference was given where possible to the preterite subjunctive, since in the $19^{\text {th }}$ century synthetic constructions were more highly valued as more original and hence superior, with periphrases regarded concomitantly as a sign of `Sprachverfallı, cf. Durrell (2014, p. 22). If the würde-construction was to be used at all, it was in the apodosis, where its presence could be justified by reference to its clear expression of a future consequence should the condition given in the protasis be fulfilled. This rationalization is still given very clear expression by Brinkmann (1971, p. 378):

»Im Konditionalgefüge bleibt die würde-Fügung im allgemeinen auf den Folgerungssatz beschränkt, weil der Bedingungssatz den Fall nennt, der für die Vorwegnahme gilt: Gäbe ich mich, wie ich bin, so würde ich bis in den Nachmittag im Bett liegen.»

but it is already evident in Heyse (1838, pp. 770 f.), as in Götzinger (1838, p. 526), who states: 
»Der Conditionalis gilt übrigens nur für die Thatsache, welche für bestimmte Fälle gefolgert wird; nie aber kann er in dem Satze eintreten, der den angenommenen Fall selbst enthält, aus welchem gefolgert wird. Hier können alle andern Redeweisen stehen, nur nicht der Conditionalis."

The earliest reference to this rule for standard German which we have been able to find is in Bauer (1827-33, 3, pp. 119 f.) who refers in a footnote to a review of Reinbeck (1821) in the >Ergänzungsblätter der halleschen Literaturzeitung 139 « of December 1822. This criticizes an example of Reinbeck's with würde in the protasis, i. e. würde er zu mir kommen, so würde ich ihm sagen, as `falsch ‘ because:

»Nach dem besten Sprachgebrauch findet die Umschreibung des Conjunctivs mit ich würde nur da statt, wo eine von einer Bedingung abhängigen Handlung (u.s.w.) unbestimmt (ungewiß) ausgedrückt werden soll: [...] nicht aber nach der Bedingung selbst, nach dem wenn, wo nothwendig der einfache Conjunctiv (`nein` Conditionalis) steht. ${ }^{11}$

Bauer (1827-33, 3, pp. 123-125) himself makes the further comment that the use of würde in both protasis and apodosis may be avoided »des Wohllauts wegen«, and, following an extended discussion of other opinions on the correct use of the periphrasis, he concludes,

»daß in unzähligen Fällen beide Formen wirklich gleich gewöhnlich, und auch so gleichbedeutend wie untadelhaft sind. [...] wir fühlen auch, daß wir besonders bei wenn selten die umschreibende Form nehmen, ob wir sie gleich zuweilen nehmen können, wie wir z. B. sagen können: wenn er mir Vorwürfe machte, oder auch machen würde, (hier vielleicht, weil die erste, einfache Form leicht für den gleichlautenden Indicativ gehalten werden könnte, so daß also das Streben nach Deutlichkeit die umschreibende Form vorziehen ließe). [...] Aber, wie gesagt, gründlich und vollständig hat wohl noch kein Sprachlehrer den Unterschied dieser beiden Formen aufgestellt.«

The account by Bauer (1827-1833) is interesting because he is clearly trying in a serious way to observe and describe actual usage and reconcile this with prescription, and he is ultimately rather sceptical as to the validity of an absolute prescription against the use of würde in the protasis. However, his observation that it is less frequent there, although it could be used, corresponds with our findings on the basis of the GerManC-corpus that the use of the würde-form did indeed decrease in the protasis and increase in the apodosis in the $18^{\text {th }}$ century. As suggested earlier, this development in usage might originally have been motivated by a desire on the part of speakers to express temporality together

11 NB: The words and phrases in parentheses in this quotation would appear to be emendations by Bauer. 
with modality more explicitly, but, as Bauer recognized, by the early $19^{\text {th }}$ century there seems no longer to have been a clear distinction in meaning between the synthetic and analytic forms, cf also Brooks (2015), and it would seem that unsystematic observation of the tendency to use the würde-form predominantly in the apodosis and the synthetic preterite subjunctive in the protasis led prescriptivists searching for a distinction between the forms to elevate this tendency to an absolute rule of the standard language, with the later consequences described in Durrell (2007; 2014, pp. 21-26). In this paper we hope to have shown, on the basis of a larger body of data than has previously been available, how usage of the würde + infinitive construction evolved in the $17^{\text {th }}$ and $18^{\text {th }}$ centuries in competition with the synthetic preterite subjunctive and thereby to have provided a framework for a more adequate assessment of the place of the construction in the tense/mood paradigms of modern German, and for understanding the reasons why this has proved so difficult since the earliest tentative analyses by Bauer (1827-1833).

\section{References}

Bauer, Heinrich 1827-1833: Vollständige Grammatik der neuhochdeutschen Sprache, 5 vols., Berlin.

Bausch, Karlheinz 1979: Modalität und Konjunktivgebrauch in der gesprochenen deutschen Standardsprache. Sprachsystem, Sprachvariation und Sprachwandel im heutigen Deutsch, Teil I, München.

Behaghel, Otto 1924: Deutsche Syntax. Eine geschichtliche Darstellung, Band II: Die Wortklassen und Wortformen, Heidelberg.

Biber, Douglas, Edward Finegan and Dwight Atkinson 1993: ARCHER and its challenges. Compiling and exploring a representative corpus of historical English registers, in: Jan Aarts et al. (eds.): English Language Corpora. Design, Analysis and Exploitation, Amsterdam, pp. 1-13.

Blatz, Friedrich 1895-1896: Neuhochdeutsche Grammatik mit Berücksichtigung der historischen Entwickelung der deutschen Sprache, 2 vols., $3^{\text {rd }}$ edn., Karlsruhe.

Boye, Kasper 2012: Epistemic Meaning: A Crosslinguistic and Functional-Cognitive Study, Berlin and New York.

Brinkmann, Hennig. 1971: Die deutsche Sprache, Gestalt und Leistung, Düsseldorf.

Brooks, Thomas 2015: >Diese bedingungslose Liebe zu den Sprachfehlern ... - Sprachgeografische Betrachtungen zur würde-Umschreibung am Beispiel Robert Musil, in: Alexandra N. Lenz and Manfred M. Glauninger (eds.): Standarddeutsch im 21. Jahrhundert - Theoretische und empirische Aspekte mit einem Fokus auf Österreich, Wien (Wiener Arbeiten zur Linguistik 1), pp. 237-250.

Bybee, Joan L., William Pagliuca and Revere D. Perkins 1991: Back to the future, in: Bernd Heine and Elisabeth Closs Traugott (eds.): Approches to Grammaticalization, vol. 2, Amsterdam and Philadelphia, pp. 17-58.

- 1994: The Evolution of Grammar: Tense, Aspect and Modality in the Languages of the World, Chicago and London. 
Campbell, Lyle (ed.) 2001: Grammaticalization. A Critical Assessment, in: Language Sciences 23/ 2-3 (special issue).

Comrie, Bernard 1985: Tense, Cambridge.

-1986: Conditionals: A typology, in: Elisabeth Closs Traugott (ed.): On Conditionals, Cambridge, pp. 77-99.

Dal, Ingerid 2014: Kurze deutsche Syntax auf historischer Grundlage, $4^{\text {th }}$ edn., revised by HansWerner Eroms, Berlin and Boston.

Donhauser, Karin and Michail L. Kotin 1999: Über die historische Entwicklung der Umschreibung würde+Infinitiv im Deutschen, unpublished Manuscript, Humboldt-Universität Berlin.

Drosdowski, Günther and Helmut Henne 1980: Tendenzen der deutschen Gegenwartssprache, in: Hans-Peter Althaus et al. (eds.): Lexikon der germanistischen Linguistik, $2^{\text {nd }}$ ed., Tübingen, pp. 619-632.

Duden 1984: Grammatik der deutschen Gegenwartssprache, $4^{\text {th }}$ edn., Mannheim [etc.].

Duden 2009: Die Grammatik, $8^{\text {th }}$ edn., Mannheim [etc.].

Durrell, Martin 2007: >Deutsch ist eine würde-lose Sprache«. On the history of a failed prescription, in: Stefan Elspaß et al. (eds.): Germanic Language Histories sfrom Below<, Berlin and New York (Studia Linguistica Germanica 86), pp. 243-258.

- 2014: Mit der Sprache ging es immer schon bergab. Dynamik, Wandel und Variation aus sprachhistorischer Perspektive, in: Albrecht Plewnia and Andreas Witt (eds.): Sprachverfall? Dynamik - Wandel - Variation, Berlin and Boston (Institut für deutsche Sprache: Jahrbuch 2013), pp. 11-31.

- 2015: `Representativenessく, ১Bad Data and legitimate expectations. What can an electronic historical corpus tell us that we didn't actually know already (and how)?, in: Jost Gippert and Ralf Gehrke (eds.): Historical Corpora. Challenges and Perspectives, Tübingen (Corpus Linguistics and Interdisciplinary Perspectives on Language 5), pp. 13-33.

DWb $=$ Grimm, Jacob and Wilhelm Grimm 1854 ff.: Deutsches Wörterbuch, 33 vols., Leipzig.

Ebert, Robert Peter, Oskar Reichmann, Hans-Joachim Solms and Klaus-Peter Wegera 1993: Frühneuhochdeutsche Grammatik, Tübingen.

Eisenberg, Peter 1989: Grundriß der deutschen Grammatik, $2^{\text {nd }}$ edn., Stuttgart.

- 2006: Grundriss der deutschen Grammatik, vol. 2: Der Satz, $3^{\text {rd }}$ edn., Stuttgart and Weimar.

Elspaß, Stefan 2014: Prescriptive norms and norms of usage in nineteenth-century German, in: Gijsbert Rutten et al. (eds.): Norms and Usage in Language History 1600-1900. A Sociolinguistic and Comparative Perspective, Amsterdam and Philadelphia (Advances in Historical Sociolinguistics 3), pp. 303-320.

Erdmann, Oskar 1886: Grundzüge der deutschen Syntax nach ihrer geschichtlichen Entwicklung, Stuttgart.

Fabricius-Hansen, Cathrine 2000: Die Geheimnisse der deutschen würde-Konstruktion, in: Rolf Thieroff et al. (eds.): Deutsche Grammatik in Theorie und Praxis, Tübingen, pp. 83-96.

Fernandez Bravo, Nicole 1980: Geschichte der indirekten Rede im Deutschen vom siebzehnten Jahrhundert bis zur Gegenwart, in: Deutsche Sprache 8, pp. 97-132.

Fleischer, Jürg 2011: Historische Syntax des Deutschen. Eine Einführung, Tübingen.

Fourquet, Jean 1970: Prolegomena zu einer deutschen Grammatik, Düsseldorf (Sprache der Gegenwart 7).

Fritz, Thomas A. 2000: Futur, Modalität und Sprecherbezug im Deutschen, Hamburg (Beiträge zur deutschen Sprachwissenschaft 16).

Götzinger, Max Wilhelm 1836: Die deutsche Sprache und ihre Literatur, vol. 1: Die deutsche Sprache, Theil I, Stuttgart. 
Guchman, Mirra M. and Natalja N. Semenjuk 1981: Zur Ausbildung der Norm der deutschen Literatursprache im Bereich des Verbs (1470-1730). Tempus und Modus, Berlin (Bausteine zur Sprachgeschichte des Neuhochdeutschen 56/V)

Helbig, Gerhard and Joachim Buscha 1986: Deutsche Grammatik. Ein Handbuch für den Ausländerunterricht, $9^{\text {th }}$ edn., Leipzig.

Herdin, Eduard 1903: Würde + Infinitiv als ıIndikativ Futuri praeteriti gebraucht, in: Zeitschrift für den deutschen Unterricht 17, pp. 191-208.

- 1905: Über würde mit dem Infinitiv, in: Zeitschrift für den deutschen Unterricht 19, pp. 81-103.

Heyse, Johann Christian August 1838: Theoretisch-praktische Grammatik der deutschen Sprache oder Lehrbuch der deutschen Sprache nebst einer Geschichte derselben, $5^{\text {th }}$ edn., revised by Karl Wilhelm Ludwig Heyse, Hannover.

Huddleston, Rodney and Geoffrey K. Pullum 2002: The Cambridge Grammar of the English Language, Cambridge.

Jäger, Siegfried 1971: Der Konjunktiv in der deutschen Sprache der Gegenwart. Untersuchungen an ausgewählten Texten, München and Düsseldorf (Heutiges Deutsch, Reihe I, Band 1).

Jørgensen, Peter 1966: German Grammar III. Revised edition translated by Gertrud Kolisko in consultation with the author and with Frederick P. Pickering, London.

Kotin, Michail L. 2003: Die werden-Perspektive und die werden-Periphrasen im Deutschen, Frankfurt/Main [etc.] (Danziger Beiträge zur Germanistik 8).

Leirbukt, Oddleif (ed.) 2004: Tempus/Temporalität und Modus/Modalität im Sprachenvergleich, Tübingen (Eurogermanistik 18).

Lenders, Winfried and Klaus-Peter Wegera 1982: Maschinelle Auswertung sprachhistorischer Quellen. Ein Bericht zur computerunterstützten Analyse der Flexionsmorphologie des Frühneuhochdeutschen, Tübingen (Sprache und Information 3).

Lyons, John 1977: Semantics, 2 vols., Cambridge.

McEnery, Anthony and Andrew Hardie 2012: Corpus Linguistics. Method, Theory and Practice, Cambridge.

Palmer, Frank R. 2001: Mood and Modality, $2^{\text {nd }}$ edn., Cambridge.

Paul, Hermann 1920: Deutsche Grammatik, Band IV, Teil IV: Syntax (zweite Hälfte), Halle/Saale.

- 2007: Mittelhochdeutsche Grammatik, $25^{\text {th }}$ edn., revised by Thomas Klein, Hans-Joachim Solms and Klaus-Peter Wegera, Tübingen.

Reinbeck, Georg 1821: Regellehre der deutschen Sprache: Zum Gebrauche für die oberen Klassen der Gymnasien und Lyceen, Essen.

Samuels, Michael L. 1972: Linguistic Evolution. With Special Reference to English, Cambridge.

Sapp, Christopher and Dorian Roehrs: The rise of the adjectival quantifier viel and the loss of genitive case assignment, in: Journal of Germanic Linguistics 28, pp. 89-166.

Schanen, François and Jean-Paul Confais 1986: Grammaire de l'allemand. Formes et fonctions, Paris.

Scheible, Silke, Richard J. Whitt, Martin Durrell and Paul Bennett 2011a: A gold standard corpus of Early Modern German, in: Proceedings of the $5^{\text {th }}$ LAW Workshop, Stroudsburg, PA, pp. 124-128.

- 2011b: Investigating diachronic grammatical variation in Early Modern German: Evidence from the GerManC Corpus. in: Marek Konopka et al. (eds.): Grammar and Corpora 2009. Third International Conference, Tübingen (Corpus Linguistics and Interdisciplinary Perspectives on Language 1), pp. 539-547.

Schröder, Werner 1959: Zu Wesen und Bedeutung des würde + Infinitiv-Gefüges, in: Wirkendes Wort 9, pp. 70-84. 
Smirnova, Elena 2006: Die Entwicklung der Konstruktion würde + Infinitiv im Deutschen. Eine funktional-semantische Analyse unter besonderer Berücksichtigung sprachhistorischer Aspekte, Berlin and New York (Studia Linguistica Germanica 82).

- 2007: Rekonstruktion eines Grammatikalisierungsprozesses. Entwicklung der Konstruktion würde + Infinitiv zum Konjunktiv II-Grammem, in: Zeitschrift für Dialektologie und Linguistik 74, pp. 20-37.

Steube, Anita 1985: Erlebte Rede aus linguistischer Sicht, in: Zeitschrift für Germanistik 6, pp. 389-406.

Szatzker, Szilvia 2002: Die Grammatikalisierung von werden/würde + Infinitiv im Neuhochdeutschen (1650-2000), unpublished PhD thesis, Eötvös Loránd University, Budapest.

- 2003: Überlegungen zur Grammatikalisierung von würde + Infinitiv im Neuhochdeutschen (1650-2000), in: Attila Németh (ed.): Linguistische Beiträge ungarischer Nachwuchswissenschaftler. Referate der 1. Linguistischen Tagung ungarischer Nachwuchsgermanisten an der Universität Veszprém vom 28.-29. März 2003, Wien, pp. 187-208.

- 2012: Zur Grammatikalisierung des FuturPräteritums im Deutschen, in: Elisabeth Lang et al. (eds.): Schnittstellen: Sprache - Literatur - Fremdsprachendidaktik, Hamburg (Studien zur Germanistik 43), pp. 141-153.

Thieroff, Rolf 1992: Das finite Verb im Deutschen. Tempus - Modus - Distanz, Tübingen (Studien zur deutschen Grammatik 40).

- 2004: Modale Tempora - non-modale Modi. Zu Bedeutung und Gebrauch inhärenter Verbkategorien in verschiedenen europäischen Sprachen, in: Oddleif Leirbukt (ed.), pp. 63-85.

Vater, Heinz 1975: Werden als Modalverb, in: Johann P. Calbert and Heinz Vater (eds.): Aspekte der Modalität, Tübingen (Studien zur deutschen Grammatik 1), pp. 71-148.

Vuillaume, Marcel 2004: Zum Ausdruck von ıZukunft in der Vergangenheit im Französischen und Deutschen, in: Oddleif Leirbukt (ed.), pp. 169-189.

Watts, Richard J. 2011: Language Myths and the History of English, Oxford.

Wegera, Klaus-Peter 2013: Language data exploitation. Design and analysis of historical language corpora, in: Paul Bennett et al. (eds.): New Methods in Historical Corpora, Tübingen (Corpus Linguistics and Interdisciplinary Perspectives on Language 3), pp. 55-73.

Weinrich, Harald 2003: Textgrammatik der deutschen Sprache, $2^{\text {nd }}$ edn., Hildesheim.

Welke, Klaus 2005: Tempus im Deutschen. Rekonstruktion eines semantischen Systems, Berlin and New York (Linguistik - Impulse und Tendenzen 13).

Wolf, Norbert Richard 1995: würde. Zur Verwendung einer Hilfsverbform, in: Heidrun Popp (ed.): Deutsch als Fremdsprache. An den Quellen eines Faches. Festschrift für Gerhard Helbig zum 65. Geburtstag, München, pp. 193-202.

Zifonun, Gisela, Ludger Hoffmann and Bruno Strecker 1997: Grammatik der deutschen Sprache, 3 vols., Berlin and New York. 